ENTREPRENEURSHIP AND SUSTAINABILITY ISSUES

ISSN 2345-0282 (online) http://jssidoi.org/jesi/ 2019 Volume 7 Number 1 (September)

http://doi.org/10.9770/jesi.2019.7.1(20)

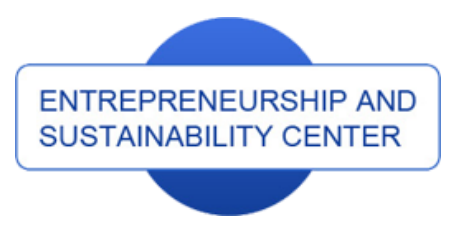

Publisher

http://jssidoi.org/esc/home

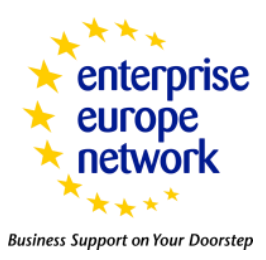

CASPA

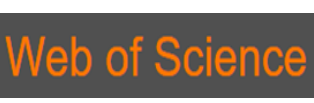

1) Clarivate

\title{
REALIZATION OF PPP PROJECTS IN THE SECTOR OF ENERGETICS AS A CONDITION OF A SUSTAINABLE DEVELOPMENT OF MACROREGIONS*
}

\author{
Lyudmila Tolstolesova ${ }^{1}$, Natalya Yumanova ${ }^{2}$, Ekaterina Mazikova $^{3}$, Igor Glukhikh ${ }^{4}$, \\ Marina Vorobieva ${ }^{5}$
}

\author{
${ }^{1,2,3}$ Tyumen state university, Institute of Economics and Finance, Lenina Str.16, Tyumen, Russian Federation \\ ${ }^{4,5}$ Tyumen state university, Institute Of Mathematics And Computer Science, Perekopskaya Str. 15A, Tyumen, Russian \\ Federation \\ E-mails: ${ }^{1}$ l.a.tolstolesova@utmn.ru, ${ }^{2}$ n.n.yumanova@utmn.ru, ${ }^{3}$ e.v.mazikova@utmn.ru, ${ }^{4}$ i.n.glukhikh@utmn.ru, \\ ${ }^{5}$ m.s.vorobeva@utmn.ru
}

Received 22 April 2019; accepted 10 July 2019; published 30 September 2019

\begin{abstract}
The article deals with the problems of implementation of public-private partnership programs in the energy sector aimed at ensuring the sustainable development of macro-regions. It is determined that in the financing of PPP energy projects, the World Bank institutions evaluate the projects for the selection of the most effective and ready for implementation, based on a variety of criteria. This assessment gives priority to projects that are based on renewable energy sources and those that are more environmentally friendly. The problems and uncertainties associated with the implementation of PPP projects in the energy sector are identified.
\end{abstract}

Keywords: sustainable development; public-private partnership projects; energy sector; World Bank; macro-regions; project evaluation and selection; financing; funding organization

Reference to this paper should be made as follows: Tolstolesova, L.; Yumanova N.; Mazikova E.; Glukhikh I.; Vorobieva, M. 2019. Sustainability issues of territorial power systems in market conditions, Entrepreneurship and Sustainability Issues 7(1): $263-277$. http://doi.org/10.9770/jesi.2019.7.1(20)

JEL Classifications: O19, O57, P18, Q42, Q43

\section{Introduction.}

Disproportions, appearing in the structure of economics, its low economic efficiency (both of parts of it and in general) can lead to a slowdown of a sustainable development and an emergence of regions inside the countries

\footnotetext{
* The study was prepared with the support of the Russian Foundation for basic research (RFBR), grant agreement No. 19010-00975
} 


\section{ENTREPRENEURSHIP AND SUSTAINABILITY ISSUES}

ISSN 2345-0282 (online) http://jssidoi.org/jesi/ 2019 Volume 7 Number 1 (September) http://doi.org/10.9770/jesi.2019.7.1(20)

and macro regions with negative dynamics of readings of socio-economic development. This situations is at dissonance with an accepted concept of the sustainable development and can contribute to stagnation of economics increase in poverty and growth of other economic and social problems on a global scale. Support of the regions and countries provided by state bodies, international financial institutions and a private sector is becoming an important task directed towards forming modern infrastructure especially of facilities in the sector of energetics, creating a foundation for industrial and socio-economic development. Applying the mechanisms of public-private partnership creates conditions for attraction of resources of big private investors and credit resources of banks, including international financial institutions.

In this regard, it is important to conduct a comprehensive study of the problems of public-private partnership projects in the field of energy to ensure sustainable development of various regions of the world, as well as the evaluation of projects, the choice of those that will receive financial support from international financial institutions.

\section{Interconnection and interdependence of development of energetics and the sustainable development}

A sustainable development, the concept of which was first introduced by The United Nations Conference on Environment and Development (UNCED) in 1992 supposes development, allowing sustainable long term economic growth not leading to environmental degradation (Earth summit 1992). Achievement of the stable economic growth will require changes in the way manufacturing processes is organized, types and volume of resources used and also in products manufactured. (National Research Council 1995) A shift towards sustainable development presupposes that "Industrially developed countries would have to take special responsibility not only because of their ecological sins of the past but also for their current technological know-hows and financial resources" (A. Merkel 1997). Stable progressive advance both of separate regions and countries in general is primarily connected with a necessity of forming modern competitive structure of economics based on high-tech and power-efficient manufactures organized in such a way to minimize and reuse existing waste products. In turn, the creation of a modern structure of the economy is largely determined by the existing level of energy supply of industrial programs of economic entities and capacity to increase energy capacity while increasing the need for them.

Over the past decades of multiple discussions about a connection between energetics, environment and society, international community has officially recognized a deep interconnection between energetics and the sustainable development (Colombo E., Mattarolo L. 2017; Tvaronavičienè, M., Nesterova, K., Kováčik, V. 2017; Smaliukienė, R. Monni, S. 2019; Masood, O., Tvaronavičienė, M., Javaria, K. 2019; Sarma, U., Karnitis, G., Zuters, J., Karnitis, E. 2019).

In addition, it is shown that sustainable development largely depends on the evolution of energy technologies. If dependence on fossil fuels is unavoidable in the short term, renewable energy based on solar and wind energy or biomass will be preferred in the long term. (National Research Council 1995) In the future, nuclear energy will continue to be important, provided that nuclear facilities are used safely and the nuclear waste generated there is carefully managed. Safe nuclear energy is an indispensable source that provides new opportunities for energy conservation, distribution and use.

The directions of development of the world economy until 2030 define access to electricity as a necessary condition for the fight against poverty, since the provision of affordable, efficient, stable, safe and clean energy in sufficient quantities is not yet available to all (Colombo E., Mattarolo L. 2017). 


\section{ENTREPRENEURSHIP AND SUSTAINABILITY ISSUES}

ISSN 2345-0282 (online) http://jssidoi.org/jesi/

2019 Volume 7 Number 1 (September)

http://doi.org/10.9770/jesi.2019.7.1(20)

If nowadays the biggest success is achieved in usage of wind power, in mid-term there will be growth in importance of solar energy with usage of photoelectric technologies" (A. Merkel 1997). Nuclear power would not stop to be used either. In the last decade, both developed and developing countries pay great attention to alternative energetics on foundation of renewable energy sources in their programmatic documents. It is not a coincidence that the major international specialized exhibition "EXPO 2017. Astana" held under the motto "Energy of the future" was devoted to power-saving and alternative energy sources, development of "green" technologies, and forms of participations of businesses and governments in such projects (Expo 2017 in Astana).

At the same time, the modern reality is that when implementing sustainable economic development programs, most enterprises, along with the accumulation of material, labor and financial resources, face a serious problem caused by the complete or significant lack of power supply facilities, energy generation systems, transmission and distribution systems. Underdevelopment of sector of energetics or its lagging behind in its turn doesn't allow creating and developing industrial, engineering transport and social-domestic infrastructure facilities, expand and modernize existing manufactures. The problem of energy supply and access is particularly acute for developing countries (Agarchand N., Laishram B. 2017; Chotia, V., Rao, N. V. M. 2018; Ebhota, W. S., Inambao, F. L. 2017; Kwame A. 2011; Luo, Z., Yang, K., Cen, K., He, J., Han, T. 2018; Ogundari, I. O., Otuyemi, F. A. 2009).

Sub-Saharan Africa and South Asia have the largest electricity deficit. In these regions, energy facilities are created mainly from scratch, using new technologies and capacities, mainly based on renewable energy sources. The capacity of these countries is limited and such projects are unlikely to be implemented without the participation of the private sector. The countries of South Asia are not sufficiently provided with energy, despite the projects implemented here, which are significant for the energy sector. The region also needs large investments for further energy development (Analysis of voluntary national reviews related to sustainable development 2018).

A serious problem of many macro regions is an existing gap in availability of electric power between urban and rural areas which is typical for almost $87 \%$ of world's population. In recent times developed countries face this problem as well, during introduction of alternative energy projects, which also supposes large investments which could be raised by combining state's sources of funding and private equity (Merkel A.1997; Daniel, Z., Craig, D., Schaich, L., Morgan, S. 2019; Ebhota, W. S., Inambao, F. L. 2017). Therefore, the main efforts in the future should be aimed at improving the efficiency of energy supply and consumption, the use of less polluting fuels, as well as the search for and pooling of sources of financing in these areas.

\section{Realization of PPP projects in the sector of energetics with support of The World bank: State and tendencies of financing}

Realization of the projects in the area of energetics, even not large ones presupposes substantial value of capital investments, great pay-off period, high risks, therefore its realization by capacities of only economic entities, regions, and separate countries becomes a task difficult or often impossible to implement. In projects of this scale in the energy sector, the development of alternative energy sources, it is advisable to combine the efforts of the state and business on PPP terms with the involvement of international financial institutions.

Quite a wide range of issues related to the use of public-private partnership in the energy sector in different regions of the world is reflected in the modern literature (for example, Agarchand N., Laishram B. 2017, Romero M.J. 2015, Chotia, V., Rao, N.V.M. 2018, Daniel, Z., Craig, D., Schaich, L., Morgan, S. , Delmon J. 2010, Ebhota, W. S., Inambao, F. L. 2017, Kwame A.2011, Luo, Z., Yang, K., Cen, K., He, J., Han, T. 2018, Ogundari, I. O., Otuyemi, F. A. 2009, Xu, Y., Chang, W. 2017) The above authors have made a significant contribution to the development of research on this topic. Summing up the results of the study, the following points can be noted. 
Participation of the state in energy projects as a concession or a mechanism of public-private partnership is a fairly common practice all over the world. This is due to the fact that although such projects are quite capitalintensive and have a long payback period, they are also, due to the scale, are the most promising. When implementing PPP projects in the field of energy, both specific features (seasonal and daily fluctuations in energy consumption) and possible risks ( risk in the sale of future products, the risk of price fluctuations, the risk of developing alternative energy sources, environmental risk, etc.).

Recent energy projects have been implemented in developing countries, including with the participation of foreign private investors in public - private partnerships. Such projects are actively supported by the World Bank Group, other international financial and credit institutions and private investors. In the period years 2009-2013 there was a tendency of outstripping growth of investments in energy on the basis of PPP projects, but in years 2014-2015 investments in the transport sector took the first place. The years 2016-2017 were again marked by an increase in investment in energy, thanks to the implementation of 6 large-scale PPP projects to generate electricity in Indonesia, Pakistan and Jordan. In 2017, investments were made in 10 PPP projects in Vietnam, 9 of which use renewable energy sources and 1 energy mega-project using coal worth 1.9 billion USD (Private Participation in Infrastructure (PPI) 2018).

In 2017, investments in Indonesian energy PPP projects increased by a total of 8.2 billion USD, including 2 coal mega-projects by 4.2 and 2.2 billion USD. In 2018, the volume of PPP investments in the country's energy projects fell to 1.1 billion USD; only 4 energy projects were supported. Despite the increase in credit investments in PPP projects since 2016, there is a decrease in the investment share of the private sector in energy projects due to the growth of investments in transport. In the year 2016 this share was 66\%, in the year 2018 it declined to $36 \%$. However, compared with other sectors of economics, energy PPP projects are still attractive for investments and are more than a third of them (Private Participation in Infrastructure (PPI) 2018).

International Bank for Reconstruction and Development (IBRD) and International Development Association (IDA) as the biggest structures of The World Bank are actively participating in financing PPP energy projects in participating countries which is shown in the given data in the context of macro regions (Table 1).

Table 1. Dynamics of crediting by IBRD and IDA in the sector of energetics in the context of regions in 2014-2018, million USD

\begin{tabular}{|c|c|c|c|c|c|c|c|}
\hline Sector & $\begin{array}{l}\text { South } \\
\text { Africa }\end{array}$ & $\begin{array}{l}\text { East Asia and } \\
\text { Pacific Region }\end{array}$ & $\begin{array}{l}\text { Europe and } \\
\text { central Asia }\end{array}$ & $\begin{array}{l}\text { Latin America an } \\
\text { the Caribbean }\end{array}$ & $\begin{array}{l}\text { Middle East and } \\
\text { North Africa }\end{array}$ & $\begin{array}{l}\text { South } \\
\text { Asia }\end{array}$ & Total \\
\hline \multicolumn{8}{|c|}{ IBRD obligations } \\
\hline \multicolumn{8}{|l|}{ Including } \\
\hline Energetics & 1,063 & 3,021 & 5,449 & 1,665 & 4,183 & 2,62 & 18,001 \\
\hline \multicolumn{8}{|c|}{ IDA obligations } \\
\hline $\begin{array}{l}\text { Total, all sectors of } \\
\text { economics }\end{array}$ & 55,339 & 9,593 & 3,256 & 1,889 & 1,85 & 28,923 & 100,849 \\
\hline \multicolumn{8}{|l|}{ Including } \\
\hline Energetics & 8,574 & 832 & 600 & 67 & 138 & 4,426 & 14,637 \\
\hline $\begin{array}{l}\text { In\% of the total } \\
\text { loans granted }\end{array}$ & 15,5 & 8,7 & 18,4 & 3,5 & 7,5 & 15,3 & 14,5 \\
\hline
\end{tabular}

Source: compiled by the authors on the basis of: Private Participation in Infrastructure (PPI) 2018. 


\section{ENTREPRENEURSHIP AND SUSTAINABILITY ISSUES}

ISSN 2345-0282 (online) http://jssidoi.org/jesi/ 2019 Volume 7 Number 1 (September) http://doi.org/10.9770/jesi.2019.7.1(20)

In terms of the volume of loans provided by IBRD to PPP projects in the energy sector, the three leaders are the countries of Europe and Central Asia, the Middle East and North Africa, East Asia and the Pacific. Their share of credits is 12,7 billion USD out of total credit value of 18 billion USD or almost $11 \%$ out of those given to all Economic sectors. In terms of loans to IDA Members for PPP projects in the energy sector, countries in Africa and South Asia stand out significantly. Their share is 13 billion USD with total loans of 14.6 billion USD, or 13\% of those issued to all countries in all sectors of the economy.

Considering that these macro regions suffer from substantial lack of electric power, governments of the countries together with IDA and private investors make large capital investments into PPP projects in energetics, allowing to develop economics, fight poverty and solve socially important questions. In total, 113 PPP projects in the energy sector of 58 countries were supported for the period 2014-2017, totaling 22,292 million USD. In 2017 in the countries - IDA members financial closing was achieved in 27 PPP projects in the sector of energetics realized in 16 courtiers at the total sum of 4180,13 million USD. In 7 countries, the projects are related to the creation of solar power plants (Afghanistan, Burkina Faso, Cambodia, Honduras, Mozambique, Senegal, Zambia), which is $26 \%$ of the projects, 9 projects (33\%) are related to the construction of hydroelectric power plants. (Laos, Nepal, Uganda etc.). The projects of creating power plants powered by gas (1 project), mazut ( 3 projects), wind energy ( 2 projects), thermal energy were realized. Floating power plant in Ghana and combined cycle power plant are being built 24 out of creating projects are completely new and 3 are carried out based on existing facilities. Most of the projects are implemented in 8 countries, which is $70 \%$ of all investments in 79 PPP projects. Most of the financial assistance was provided to Ghana, Lao PDR, Honduras (Table 2).

Table 2. IDA countries with the highest investment and the number of PPP projects in the energy sector

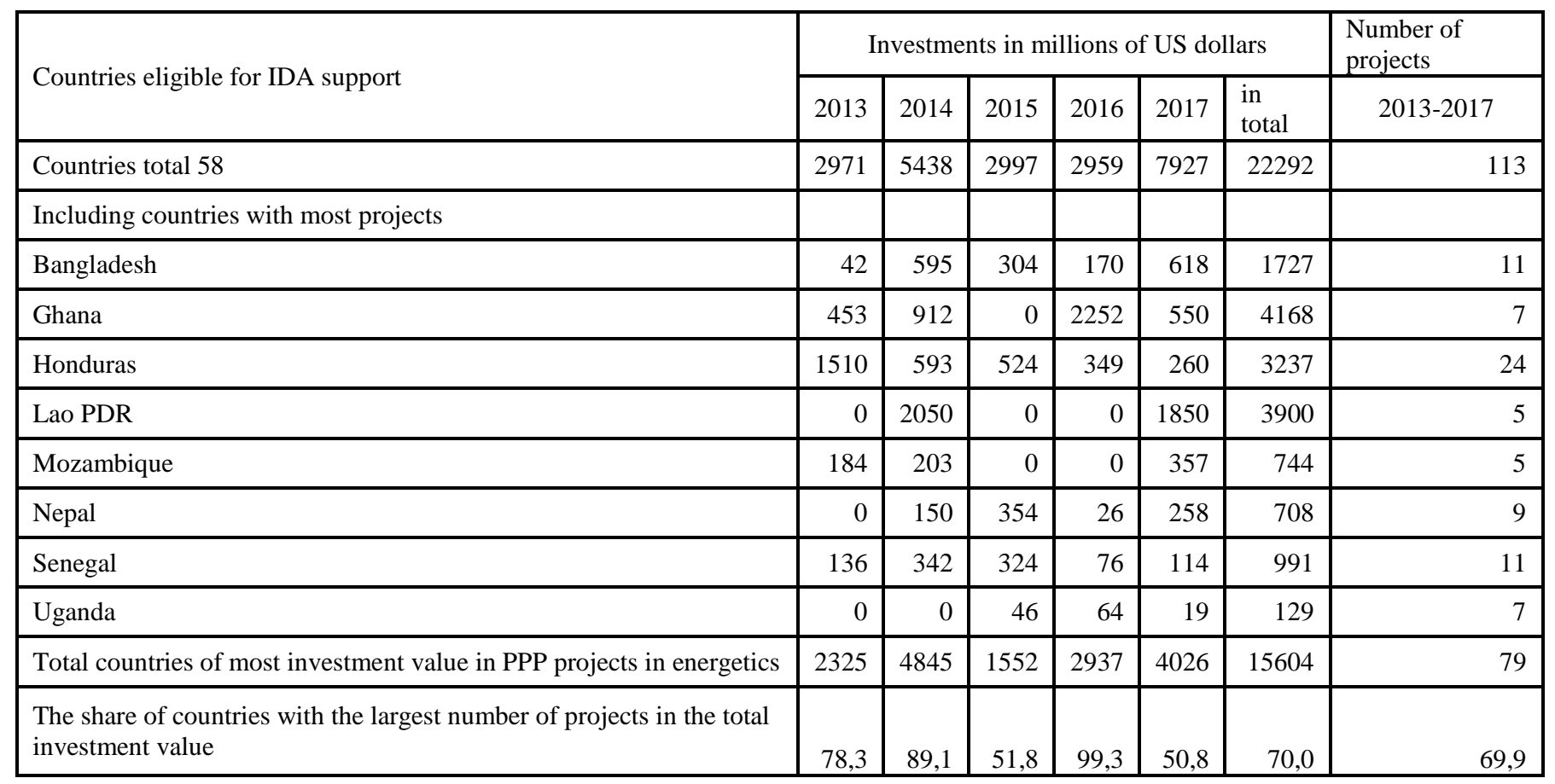

Source: compiled by the authors on the basis of: Private Participation in Infrastructure (PPI). 2018

State Bodies and World Bank structures took part in financing PPP projects alongside with different corporate bodies and also numerous regional national and international banks and other financial and credit institutions. This is due to the fact that although energy projects require large investments, they have moderate risks and 
ENTREPRENEURSHIP AND SUSTAINABILITY ISSUES

ISSN 2345-0282 (online) http://jssidoi.org/jesi/ 2019 Volume 7 Number 1 (September) http://doi.org/10.9770/jesi.2019.7.1(20)

appropriate cost recovery, especially given that their implementation uses mainly renewable energy sources. (Table3).

Table 3. Sponsors and financing banks with biggest shares in PPP projects in energetics

\begin{tabular}{|c|c|c|}
\hline IDA Countires & Sponsors & Project Banks \\
\hline \multicolumn{3}{|l|}{$\begin{array}{l}\text { Including the countries with } \\
\text { the largest number of projects }\end{array}$} \\
\hline Bangladesh & $\begin{array}{l}\text { SembCorp Industries, North West Power } \\
\text { Generation Company, Doreen Group }\end{array}$ & $\begin{array}{lcc}\text { IFC, Clifford Capital, } & \text { Commonwealt } \\
\text { Development Corporation } & \\
\end{array}$ \\
\hline Ghana & Sunseap Group, Karadeniz Energy Group & $\mathrm{ADB}$ \\
\hline Honduras & Upower Group, Grupo Terra & $\begin{array}{l}\text { FMO, DEG, G\&T Continental Bank, Agence } \\
\text { Francaise de Developpement (AFD) }\end{array}$ \\
\hline Lao PDR & $\begin{array}{l}\text { Phonesack Group, Electricity Generating } \\
\text { Company (EGCO), EDL-Generation Public } \\
\text { Company (EDL-Gen), Mega First Corp., } \\
\text { Électricité du Laos (EDL), B. Grimm } \\
\text { Group }\end{array}$ & $\begin{array}{l}\text { Bangkok Bank,, Thai Exim Bank, } \\
\text { Commercial Bank, Tisco Bank }\end{array}$ \\
\hline Mozambique & $\begin{array}{l}\text { Electricidade de Moçambique (EDM), } \\
\text { Sasol, Scatec, Electricidade de } \\
\text { Moçambique (EDM), Norfund }\end{array}$ & $\begin{array}{l}\text { IFC, FMO, EAIF, Agence Francaise de } \\
\text { Developpement (AFD), Barclays, Climate } \\
\text { Investment Funds, Private Infrastructure } \\
\text { Development Group (PIDG) }\end{array}$ \\
\hline Nepal & $\begin{array}{l}\text { Butwal Power Company (51\%) Gurans } \\
\text { Energy Limited (44\%) Asia Pacific Power- } \\
\text { Tech Co. Ltd (5\%), Ngadi Group Power } \\
\text { (Butwal Power Company (97\%) Lamjung } \\
\text { Electricity Development Company } \\
\text { (LEDCO) Beni Hydropower Project }\end{array}$ & $\begin{array}{l}\text { IFC, IDA, NMB Bank (NMB), Prabhu Bank, } \\
\text { Mega Bank, Century Bank, NCC Bank, Kumari } \\
\text { Bank, Everest Bank, Nabil Bank, Global IME } \\
\text { Bank, Himalayan Bank, Sunrise Bank,) } \\
\text { Hydroelectricity Investment and Development } \\
\text { Company, Nepal Bangladesh Bank, Vibor } \\
\text { Society Development Bank, Siddhartha Bank }\end{array}$ \\
\hline Senega & $\begin{array}{l}\text { ContourGlobal, Matelec, International } \\
\text { Finance Corporation, Small international } \\
\text { investors }\end{array}$ & OPIC EAIF, IFC, BOAD, FMO \\
\hline Uganda & $\begin{array}{l}\text { Lereko Investments, WK Power (WK) and } \\
\text { Fieldstone Africa Investment Resources } \\
\text { (FAIR) }\end{array}$ & OPIC \\
\hline
\end{tabular}

Source: compiled by the authors on the basis of: Private Participation in Infrastructure (PPI) 2018

In 2018, there was a significant increase in funding for PPP projects, which amounted to 15.7 billion USD. Almost $50 \%$ of them are investments in energy projects, mainly related to the transmission and distribution of energy. 78 out of 84 new PPP projects in the energy sector based on renewable energy sources were submitted for approval, which is on average more than in the previous 5 years. (93\% of all completed projects). The largest financial support for the implementation of PPP projects in the energy sector was provided in 2018 to the following countries: Vietnam 11 projects 3.4 billion USD; Mexico, 7 projects 1.8 billion USD; South Africa 5 projects 1.6 billion USD; India 9 projects 1.1 billion USD.

During the last decade most attention of the investors is being paid to energy projects using renewable energy sources. It is among the countries with the support of IDA and without it. It should be noted that the share of PPP projects in renewable energy in IDA countries was lower than in non-IDA countries, although the growth rate of such projects in IDA countries was significantly higher than in other countries. (Table 4). 
ENTREPRENEURSHIP AND SUSTAINABILITY ISSUES

ISSN 2345-0282 (online) http://jssidoi.org/jesi/

2019 Volume 7 Number 1 (September)

http://doi.org/10.9770/jesi.2019.7.1(20)

Table 4. Investments in public-private partnership projects in the field of renewable energy in 2013-2017

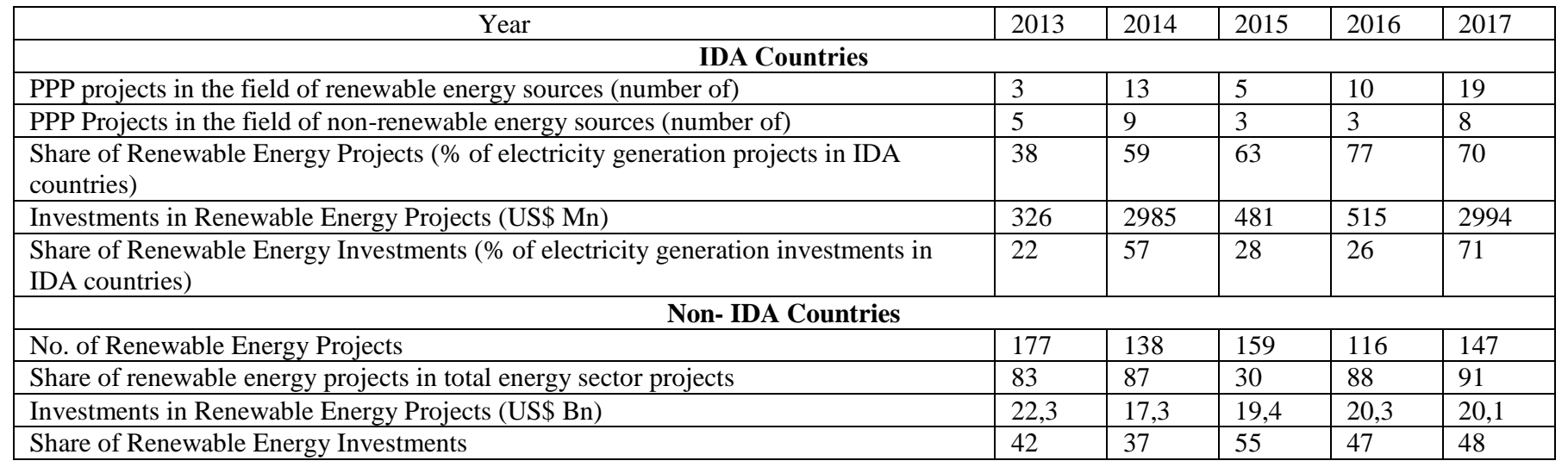

Source: compiled by the authors on the basis of Private Participation in Infrastructure (PPI) 2018

In 2018, investments in PPP projects using renewable energy sources amounted to 64\%, and traditional sources. $36 \%$ (coal energy mega-projects in Vietnam and Pakistan, natural gas - in Brazil). Projects based on renewable energy sources are arranged in the following way $35 \%$ are founded on solar energy, $22 \%$ on wind energy, $5 \%$ on geothermal energy, $1 \%$ to water and biomass energy, $0.5 \%$ on usage of wastes. Solar energy has become predominant; 49 projects have been registered in 23 countries. Leaders are 6 projects in India, Brazil, Vietnam and Ukraine (5 projects each). Wind energy is used in 20 PPP projects in 7 countries.

In the countries of Europe and Central Asia, the energy infrastructure has been mainly established for a long time, so the public-private partnership projects implemented here are mainly aimed at its modernization, increase in repair capacity or transfer to renewable and more environmentally friendly energy sources. Developed European countries are implementing programs for the introduction of solar street lights, using modern technologies such as solar panels, as well as developing alternative power sources. In the CIS countries, projects in the energy sector also do not lead in the structure of the overall financing of infrastructure projects. For example, the share of financed projects in the energy sector was only 4\%. IBRD and IDA financed 2 projects in Uzbekistan on the implementation of energy-saving technologies in industry and energy efficiency of heat supply, which amounted to $18 \%$ of the total funding in this sector.

\section{Status of PPP projects in the energy sector in Russia}

Russia, as one of the major subjects of this macro region, over the past decade has turned from a borrower into an active lender, so the volume of loans in this area is not so great. Only 3 projects of construction of solar power plants in Russia were supported by the World Bank, which accounted for about $11 \%$ of investments among all PPP projects. The small amount of them is also caused by the fact that during the last 10 years the country experiencing a large-scale modernization in energy industry, which required substantial investments, therefore large investors independently or with help of foreign investors either completed investing in this sector or will do so in the next 2-3 years. The experience of PPP projects implementation exists in the country, but these are not large-scale projects, but projects at the regional and municipal level, so they are financed by public authorities and private companies of the same level, with occasional participation of international organizations. Analysis of the PPP projects in energetics that are being realized in Russia in the last 10 years (since 2009) allows to evaluate general condition of the sector of energetics in Russia. (Table 5). 
Table 5. PPP Projects in energetics in general structure of PPP projects in Russia

\begin{tabular}{|l|c|c|c|c|c|}
\hline \multicolumn{1}{|c|}{ PPP projects } & $\begin{array}{c}\text { Number of } \\
\text { units }\end{array}$ & Shate in total, \% & Value of investments & $\begin{array}{c}\text { Share in value of } \\
\text { investments, \% }\end{array}$ & $\begin{array}{c}\text { Value of investments } \\
\text { per project (on average) } \\
\text { mill USD. }\end{array}$ \\
\hline Total including & 3939 & 100 & 82170 & 100 & 21 \\
\hline $\begin{array}{l}\text { In the sector of } \\
\text { energectics }\end{array}$ & 1626 & 41 & 3566 & 4 & 2 \\
\hline
\end{tabular}

Source: Compiled by the authors based on data from Project initiatives support programme 2019. PPP Development Center

During the study period, energy projects accounted for the main share $-41 \%$ or 1626 projects in the total volume of PPP projects. The volume of investments in energy projects is 3566 million USD, which corresponds to only $4 \%$ of the total cost of investments in PPP projects. The average cost of investment in a PPP project in the energy sector is only us 2 million USD, which is significantly lower than for projects in other sectors of the economy. The analysis confirms that in the Russian energy sector a large number of PPP projects are small in size and are implemented mainly at the regional or municipal level. (Figure 1,2).
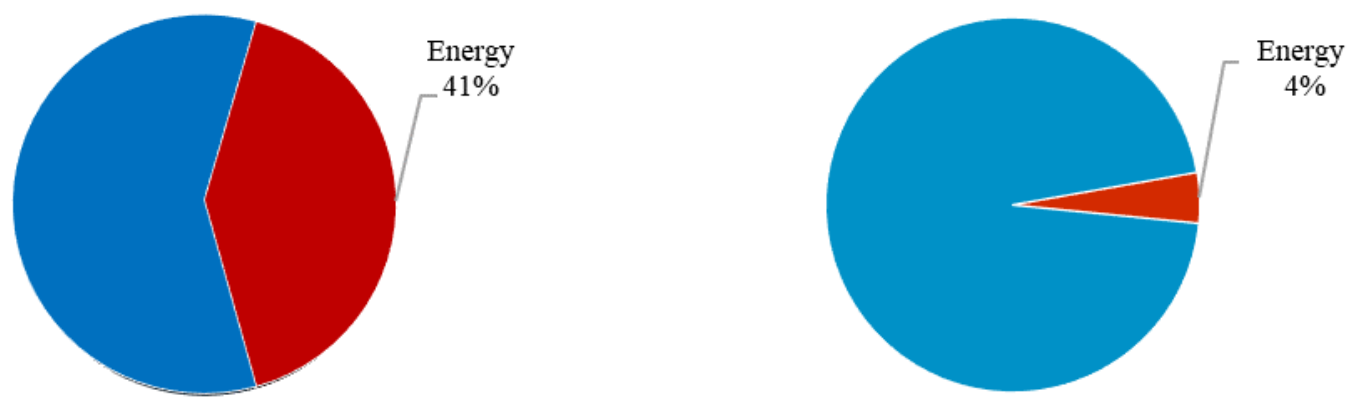

Figure 1. Share of energy projects in total PPP projects in Russia
Figure 2. Share of investments in energy projects in total investment in PPP projects in Russia

Source: Compiled by the authors based on data from Project initiatives support programme 2019. PPP Development Center.

When considering PPP projects realized in Russian sector of energetics in general it can be easily noticed that both in amount (94\%) and value of investments $(68 \%)$ predominant projects are the ones connected with heat supply. Energy supply projects account for 5 per cent of the total, while the share of investment is 32 per cent. However, the average project price in the energy sector is high. 13 million USD. This complicates the search for investors who would be willing to invest in expensive technically complex objects. (Table 6).

Table 6. The classification of PPP projects in the energy sector in Russia

\begin{tabular}{|l|c|c|c|c|c|}
\hline \multicolumn{1}{|c|}{$\begin{array}{c}\text { PPP Projects in } \\
\text { energetics }\end{array}$} & $\begin{array}{c}\text { Number of } \\
\text { projects, units. }\end{array}$ & $\begin{array}{c}\text { Share in Total } \\
\%\end{array}$ & $\begin{array}{c}\text { Value of investments } \\
\text { mill USD }\end{array}$ & $\begin{array}{c}\text { Share in total } \\
\text { value of } \\
\text { investments, } \%\end{array}$ & $\begin{array}{c}\text { Value of investments } \\
\text { per project (average) } \\
\text { mill USD }\end{array}$ \\
\hline $\begin{array}{l}\text { Total, } \\
\text { including }\end{array}$ & 1626 & 100 & 3566 & 100 & 2 \\
\hline -Heat supliues & 1530 & 94 & 2417 & 68 & 2 \\
\hline Power supplies & 88 & 5 & 1132 & 32 & 13 \\
\hline Gas supplies & 8 & 1 & 16 & 1 & 2 \\
\hline
\end{tabular}

Source: Compiled by the authors based on data from Project initiatives support programme 2019, PPP Development Center 


\section{ENTREPRENEURSHIP AND SUSTAINABILITY ISSUES}

ISSN 2345-0282 (online) http://jssidoi.org/jesi/ 2019 Volume 7 Number 1 (September) http://doi.org/10.9770/jesi.2019.7.1(20)

A conducted research has shown that projects in building of objects both of traditional and alternative energetics makes up to insignificant share in the structure of PPP projects in Russia. (6.2\%). Projects in alternative energetics are corresponding with $5 \%$ of total investment value or with 178 million USD. (Table 7). It is significantly less than the same showings in the other countries of the world. (Data in table 4).

Table 7. Projects in building new objects and alternative energy projects in the structure of PPP projects in energetics in Russia

\begin{tabular}{|l|c|c|c|c|c|}
\hline $\begin{array}{c}\text { PPP Projects in } \\
\text { energetics }\end{array}$ & $\begin{array}{c}\text { Number of } \\
\text { projects, units. }\end{array}$ & $\begin{array}{c}\text { Share in Total } \\
\%\end{array}$ & $\begin{array}{c}\text { Value of investments } \\
\text { mill USD }\end{array}$ & $\begin{array}{c}\text { Share in total } \\
\text { value of } \\
\text { investments, } \%\end{array}$ & $\begin{array}{c}\text { Value of investments } \\
\text { per project (average) } \\
\text { mill USD }\end{array}$ \\
\hline $\begin{array}{l}\text { Total, } \\
\text { including }\end{array}$ & 1626 & 100 & 3566 & 100 & 2 \\
\hline Heat supplies & 1530 & 94 & 2417 & 68 & 2 \\
\hline - Power suplies & 88 & 5 & 1132 & 32 & 13 \\
\hline Gas suplies & 8 & 1 & 16 & 1 & 2 \\
\hline
\end{tabular}

Source: Compiled by the authors based on data from Project initiatives support programme 2019. PPP Development Center.

Average sum if investments per project in alternative energy are 58 million USD versus 11 million USD for objects in traditional energetics, which is significantly higher than the same showings in other PPP projects in energetics in Russia. Average price of a PPP project in building new objects in energetics is 5 times higher than average showings in the industry. High price of the projects hinders both technical improvements in the sector of energetics and development of alternative energy. In addition, the development of alternative energy in Russia is hampered by some other significant restrictions: most regions of the country do not suffer from a lack of capacity at existing power facilities; return on investment will need to be carried out by raising tariffs; in connection with the current realities of the market, the construction of new expensive energy facilities is unlikely to receive a positive response in the market.

Analysis of the state of PPP projects in energetics depending on the stage of realization has shown the following gradation (table 8 ).

Table 8. Classification of PPP projects in energetics depending of the stage of realization of the project in Russia

\begin{tabular}{|l|c|c|c|c|c|}
\hline $\begin{array}{c}\text { Stage of realization of } \\
\text { PPP projects }\end{array}$ & Amount units & $\begin{array}{c}\text { Share in total } \\
\text { amount } \%\end{array}$ & $\begin{array}{c}\text { Value of investments } \\
\text { mill USD }\end{array}$ & $\begin{array}{c}\text { Share in value of } \\
\text { investmens } \%\end{array}$ & $\begin{array}{c}\text { Value of investments } \\
\text { per project o(on } \\
\text { average mill USD }\end{array}$ \\
\hline Pre-investment stage & 329 & 20 & 1146 & 32 & 3 \\
\hline Investment stage & 352 & 22 & 640 & 18 & 2 \\
\hline Operational stage & 896 & 35 & 1760 & 49 & 2 \\
\hline Completion & 49 & 100 & 3566 & 100 & 0,4 \\
\hline $\begin{array}{l}\text { Total PPP projects in } \\
\text { energetics }\end{array}$ & 1626 & 3 & 20 & 1 & 2 \\
\hline
\end{tabular}

Source: Compiled by the authors based on data from Project initiatives support programm. 2019. PPP Development Center.

Studies have shown that the share of completed projects is only $3 \%$, the bulk of the projects $-55 \%$ is in operation, $42 \%$ are in the pre-investment and investment stages. The distribution of investments by stages of PPP projects shows that currently about $50 \%$ of the total investment, or 1.760 million USD, has been implemented in energy projects. Continuing PPP project realization practice presupposes that 1.786 million USD will be invested into energetics sector of Russia to finish announced projects, which means further development of sector of energetics in Russia. The need for investment in the industry is high and mainly related to the implementation of small-scale generation projects, as the infrastructure of the power supply system in Russia suffers from underinvestment for 20 years, and the wear of distribution and backbone networks has reached $70 \%$ and $50 \%$ respectively. 


\section{ENTREPRENEURSHIP AND SUSTAINABILITY ISSUES}

ISSN 2345-0282 (online) http://jssidoi.org/jesi/ 2019 Volume 7 Number 1 (September) http://doi.org/10.9770/jesi.2019.7.1(20)

\section{Problems of evaluation and selection of PPP projects in the energy sector for financing by World Bank institutions}

Selection of PPP projects for financing, including projects in the sector of energetics is a difficult task, despite the fact that World Bank's regulations have developed assessment methods considering and specializing aspects of assessment. This assessment at each stage of project development includes the following areas.

1. The preparation of PPP. The legal framework and institutional framework of PPP existing in different countries are studied.

2. PPP procurement-at this stage, the process of choosing a private partner-investor responsible for the development of the PPP project is considered. Criteria such as neutrality, transparency of the process of existence or lack of competition are also considered.

3. PPP contract management. This stage characterizes the change and renegotiation of the PPP contract, dispute resolution, contract termination procedure, control over the execution of the contract and its evaluation.

4. Unsolicited proposal (USPs PPP's). It is analyzed whether legal framework allows to present such projects, implement ability of the project and its agreement with other state priorities is defined, mechanisms of compensation in case of project's realization are considered, as well as if competition to select a private investor is required.

The assessment is based on standardized questions answered by more than 13,000 participants from 135 countries. The experts identified a specific set of areas and evaluation criteria that the project should meet to the maximum extent possible in the preparation, procurement, contract management and USP phases. The areas selected for evaluation were divided into a large number of criteria. An example of the integrated project evaluation areas used at the project preparation stage and the criteria $(\mathrm{F})$ to be evaluated is shown in table 9. Similarly, other stages of PPP projects are being evaluated.

Table 9. Integrated assessment areas used in the PPP project preparation phase

\begin{tabular}{|c|c|c|c|c|c|}
\hline \multirow[t]{2}{*}{ № } & \multirow{2}{*}{$\begin{array}{l}\text { Areas of assessment at the project preparation stage } \\
\text { Preparation of PPPs }\end{array}$} & \multicolumn{4}{|c|}{ Evaluation criterion } \\
\hline & & F1 & F2 & F3 & F4 \\
\hline 1. & Approval by the Ministry of Finance or central budgetary authority & + & & & \\
\hline 2. & Fiscal treatment of PPPs (budgetary, accounting and/or reporting treatment of PPPs). & & & + & \\
\hline 3. & $\begin{array}{l}\text { Prioritization of PPP projects with all other public investment projects (for example, in the context } \\
\text { of a national public investment system) to ensure consistency of PPPs with other public } \\
\text { investment priorities.a }\end{array}$ & & + & & \\
\hline 4. & Socioeconomic analysis (cost-benefit analysis of the socioeconomic impact of the project). & & + & & \\
\hline 5. & $\begin{array}{l}\text { Fiscal affordability assessment, including the identification of the required longterm public } \\
\text { commitments (explicit and implicit) }\end{array}$ & & + & & \\
\hline 6. & Risk identification, allocation, and assessment (risk matrix).a & & + & & \\
\hline 7. & $\begin{array}{l}\text { Comparative assessment to evaluate whether PPP is the best option as } \\
\text { compared with other procurement strategies (value for money analysis, public sector comparator). }\end{array}$ & & + & & \\
\hline 8. & Financial viability or bankability assessment. & & + & & \\
\hline 9. & $\begin{array}{l}\text { Market sounding and/or assessment (showing evidence of investors' interest in the market for the } \\
\text { project).a }\end{array}$ & & + & & \\
\hline 10. & Environmental impact analysis. & & + & & \\
\hline 11. & Assessments included in the request for proposals and/or tender documents & + & & & \\
\hline 12. & Assessments published online.b & + & & & \\
\hline 13. & Draft PPP contract included in the request for proposals. & + & & & \\
\hline 14. & Tender documents published online.b & + & & & \\
\hline 15. & Standardized PPP model contracts and/or transaction documents developed & & & & + \\
\hline
\end{tabular}

Source: Procuring Infrastructure Public-Private Partnerships Report: Assessing Government Capability to Prepare, Procure, and Manage PPPs 
The most significant criteria used for the evaluation of PPP projects at the stage of their preparation, the content and ranges of evaluation are given in table 10 .

Table 10. Criteria used for selected assessment areas and their content

\begin{tabular}{|l|l|l|}
\hline № & $\begin{array}{l}\text { Evaluation } \\
\text { criterion }\end{array}$ & Content of evaluation \\
\hline 1. & F1 & $\begin{array}{l}\text { A score of 1 if yes based on a regulatory provision. } \\
\text { A score of 0.5 if yes based on a recognized practice }\end{array}$ \\
\hline 2. & F2 & $\begin{array}{l}\text { A score of 1 if required and a specific methodology has been developed. } \\
\text { A score of } 0.5 \text { if required but no specific methodology has been developed. } \\
\text { A score of } 0.25 \text { if conducted according to a recognized practice but } \\
\text { without a specific methodology developed }\end{array}$ \\
\hline 3. & F3 & $\begin{array}{l}\text { A score of } 0.5 \text { if there is a specific budgetary treatment of PPPs, based on a regulatory provision. } \\
\text { A score of } 0.25 \text { if yes based on a recognized practice. } \\
\text { A score of } 0.5 \text { if there is a specific accounting and/or reporting system for PPPs, based on a regulatory } \\
\text { provision. } \\
\text { A score of } 0.25 \text { if yes based on a recognized practice }\end{array}$ \\
\hline 4. & F4 & \begin{tabular}{l} 
A score of 1 if yes. \\
\hline
\end{tabular}
\end{tabular}

Source: compiled by the authors on the basis of: Procuring Infrastructure Public-Private Partnerships Report: Assessing Government Capability to Prepare, Procure, and Manage PPPs

If results of assessment show that PPP project can score a maximum score reaching 100 which means that problems concerning its realization are worked out in detail, chances that it will be supported is much higher than for a project having lesser score and requiring revision both in legal framework and technical details. World bank's research devoted to analysis of the quality of project's preparation of public-private partnership projects (2018) covering 135 countries has shown a necessity in improving the quality of pre-project preparation for many of them, which proves importance of thorough assessment of PPP projects back at the stage of their development.( World Bank study: countries need to improve the quality of pre-project preparation 2018.).

In the evaluation process for the subsequent selection of projects for funding, there are certain difficulties and uncertainties faced by experts:

- The PPP projects under consideration are often implemented in the "monopolized sector", including in the energy sector, when the state tries to attract private capital to infrastructure projects, while remaining their owner;

- Such projects are characterized with large scales, a long run period of realization and high capitalintensiveness, lack of a long term guaranties to a private investor;

- Insufficient development of the regulatory framework for PPP projects at the level of a potential recipient of funding;

- Lack of trained professionals necessary qualifications for the preparation of project documentation, its justification and further implementation of PPP projects;

- Insufficiently high quality of the given results of technological audit which do not allow to estimate optimality of a complex of the technologies presented in the project;

- It is not always possible to determine the real effectiveness of the project and its socio-economic impact on the development of the region, especially in the long term;

- Difficulty in assessment both of project's quality and in defining and division of risks and responsibilities between the government and a private investor. 


\section{ENTREPRENEURSHIP AND SUSTAINABILITY ISSUES}

ISSN 2345-0282 (online) http://jssidoi.org/jesi/ 2019 Volume 7 Number 1 (September)

http://doi.org/10.9770/jesi.2019.7.1(20)

\section{Conclusions}

Analysis of PPP projects in the energy sector with the support of the World Bank institutions led to a number of conclusions.

1. Priority financial support is given to projects of macro-regions that can eliminate the shortage or lack of electricity.

2. First of all, financial support is provided to projects based on renewable energy sources as more efficient.

3. When choosing projects for financing, the environmental factor-the degree of their environmental safety-is taken into account.

4. Projects that have received the maximum number of points on the basis of expert assessments according to the criteria established by the normative acts of the Bank in accordance with the current methodology are selected for financing.

5. After making a decision on financing suitable PPP energy project, institutions of World Bank usually carry out its subsequent maintenance including operation. It is determined by a number of reasons including lack of specialists of sufficient qualification in the regions where the projects are realized, insufficient quality of the projects submitted, lack of experience in realization of projects in this area, geopolitical and other risks of their realization.

6. Despite many successfully realized PPP projects in energetics all over the world, it cannot be called "win-win strategy" since in a long run even some of successful projects turned out to be nonremunerative.

Consequently, the state, creating conditions and providing certain guarantees, initiates investments for the creation of certain infrastructure, and the private sector, at its own expense, provides a significant part of the financing of the project.

\section{References}

Merkel, A. 1997. The Role of Science in Sustainable Development: The price of survival: thoughts and talks about future environmental policy. Stuttgart: German publishing house https://doi.org/10.1126/science.281.5375.336

Analysis of voluntary national reviews related to sustainable development.2018. Ensuring access to affordable, reliable, sustainable and modern energy for all. Published by the United Nations pp. https://sustainabledevelopment.un.org/content/documents/21159DESASDG7_VNR_Analysis2018_final.pdf

Agarchand, N., Laishram, B. 2017. Sustainable infrastructure development challenges through PPP procurement process: Indian perspective. International Journal of Managing Projects in Business, 10(3) https://doi.org/10.1108/IJMPB-10-2016-0078

Romero, M.J. 2015. What lies beneath? A critical assessment of PPPs and their impact on sustainable development/: Data collection closed on 30 April 2015. https://eurodad.org/files/pdf/55deebe30f047.pdf

Chotia, V., Rao, N. V. M. 2018. Infrastructure financing and economic growth in India: an Imperial investment. Journal of Financial Management of Property and Construction, 23(3), 258-273: https://doi.org/10.4172/2375-4389.1000169

Colombo, E., Mattarolo, L. 2017. Energy and development: the role of academia in education, research, and technological cooperation for sustainability. WIREs Energy Environment, 6 https://doi.org/10.1002/wene.215

Daniel, Z., Craig, D., Schaich, L., Morgan, S.2019. Driving a public-private green energy partnership: How the Maxson WWTP biogas project fuels the new 1-gigawatt combined cycle power. 91 st Annual Water Environment Federation Technical Exhibition and Conference, WEFTEC 2018. pp. 4078-4089: https://doi.org/10,2175/193864718825135919 


\section{ENTREPRENEURSHIP AND SUSTAINABILITY ISSUES}

ISSN 2345-0282 (online) http://jssidoi.org/jesi/ 2019 Volume 7 Number 1 (September) http://doi.org/10.9770/jesi.2019.7.1(20)

Delmon, J. 2010. Public-Private Partnership in Infrastructure Practical Guide for Governmental Authorities, Astana: IC “Orange. 165 pp.5

Dudin, M.N., Frolova, E.E., Protopopova, O.V., Andrey Alievich Mamedov, A.A., Odintsov, S.V. 2019. Study of innovative technologies in the energy industry: nontraditional and renewable energy sources. Entrepreneurship and Sustainability Issues, 6(4), $1704-1713$. http://doi.org/10.9770/jesi.2019.6.4(11)

Expo 2017. Specialized exposition. International Recognized Exhibition: Future's Energy. Astana. Kazakhstan: URLhttps://expo2017astana.com/

Earth summit.1992. Documents from the United Nations Conference on Environment and Development (also known as UNCED or the Earth Summit) Archived 19 January 2012 at the Wayback Machine held in Rio de Janeiro, Brazil, 1992.

Ebhota, W. S., Inambao, F. L. 2017. Facilitating greater energy access in rural and remote areas of sub-Saharan Africa: Small hydropower. Energy and Environment 28(3), pp. 316-329: https://doi.org/10.1177/0958305X16686448

Evaluating the environment for public private partnerships in Asia-Pacific. 2014. The Infrascope. A report by The Economist Intelligence Unit 2015 The Economist Intelligence Unit Ltd., and Asian Development Bank. https://www.adb.org/sites/default/files/publication/158409/2014-infrascope.pdf

Izmalkova S. A., Golovina T. A., Faustova I. L., Tronina I. A., Yeletsky S. S. 2012. Infrastructure project management: textbook for higher education. Orel: FGBOU VPO "state University of UNPK". 171 p. p. 26

Investmentsin IDA Countries Private Participation in Infrastructure (PPI) 2013 - 2017. Private Participation in Infrastructure Database. http://ppi.worldbank.org/ /media/GIAWB/PPI/Documents/Global-Notes/PPI_IDACountries_2013-2017

Investments in IDA Countries Private Participation in Infrastructure (PPI) 2013-2017 http://ppi.worldbank.org/ /media/GIAWB/PPI/Documents/Global-Notes/PPI_IDACountries_2013-2017

Kwame A.2011. The Potential for Public Private Partnership (PPP) in Ethiopia: Asubonteng Consultant in Capacity Building and Public Private Partnership Planning and Implementation Private Sector Development Hub/Addis Ababa Chamber of Commerce and Sectoral Associations: http://ethiopianchamber.com/Data/Sites/1/psd-hub-publications/the-potential-for-public-private-partnership-(ppp)-inethiopia.pdf

Luo, Z., Yang, K., Cen, K., He, J., Han, T. 2018. A study on the application of public-private partnership mode in shale gas development industry in China. .Journal of Renewable and Sustainable Energy, 10(4), 045902: https://doi.org/10.1063/1.4985945

Masood, O., Tvaronavičiene, M., Javaria, K. 2019. Impact of oil prices on stock return: evidence from G7 countries. Insights into Regional Development, 1(2), 129-137. https://doi.org/10.9770/ird.2019.1.2(4)

Ogundari, I. O., Otuyemi, F. A. 2009. Project planning and monitoring analysis for sustainable environment and power infrastructure project development in Lagos State, Nigeria. International Journal of Critical infrastructure, 15(1), 24-45. http://www.inderscience.com/link.php?id=96566

Smaliukienè, R., Monni, S. 2019. A step-by-step approach to social marketing in energy transition. Insights into Regional Development, 1(1), 19-32. https://doi.org/10.9770/ird.2019.1.1(2)

National Center for PPP. 2019. Annual report http://pppcenter.ru/analitika/

National Research Council. 1995. The Role of Technology in Environmentally Sustainable Development. A Declaration of the Council of Academies of Engineering and Technological Sciences. CAETS. Kiruna, Sweden Washington, DC: The National Academies Press. (pp.7-8) https://doi.org/10.17226/9236

Project initiatives support programme. 2019. PPP Development Center. Annual report http://www.pppi.ru

Private Participation in Infrastructure (PPI). 2018. The Word Bank: IBRD-IDA: PPI Database, World Bank, as of April 2018: http://ppi.worldbank.org/ /media/GIAWB/PPI/Documents/Global-Notes/H12018_PPI_Report

Procuring Infrastructure: Public-Private Partnerships Report: 2018. Assessing Government Capability to Prepare, Procure, and Manage PPP (p.218-224) https://ppp.worldbank.org/public-privatepartnership/sites/ppp.worldbank.org/ files/documents/ Procuring Infrastructure _ PPPs_2018_EN.pdf 


\section{ENTREPRENEURSHIP AND SUSTAINABILITY ISSUES}

ISSN 2345-0282 (online) http://jssidoi.org/jesi/ 2019 Volume 7 Number 1 (September)

http://doi.org/10.9770/jesi.2019.7.1(20)

Risk Allocation in Public-Private Partnerships: Maximizing value for Money Acknowledgements. 2015. International Institute for Sustainable Development https://www.iisd.org/sites/default/files/publications/risk-allocation-ppp-maximizing-value-for-money-discussionpaper.pdf

Rosinfra. Infrastructure project support platform. 2019. Annual report http://www.pppi.ru

Sarma, U., Karnitis, G., Zuters, J., Karnitis, E. 2019. District heating networks: enhancement of the efficiency. Insights into Regional Development, 1(3), 200-213. https://doi.org/10.9770/ird.2019.1.3(2)

The Role of Technology in Environmentally Sustainable Development. 1995. A Declaration of the Council of Academies of Engineering and Technological Sciences. CAETS. Kiruna, Sweden.

Tsurkan, M., Andreeva, S., Lyubarskaya, M., Chekalin, V., Lapushinskaya, G. 2017. Organizational and financial mechanisms for implementation of the projects in the field of increasing the energy efficiency of the regional economy. Open access: Problems and Perspectives in Management, 15(3), 453-466 http://dx.doi.org/10.21511/ppm.15(3-2).2017.13

Tvaronavičienè, M., Nesterova, K., Kováčik, V. 2017. Energy security and long-term energy efficiency: case of selected counties. Journal of Security and Sustainability Issues, 7(2), 349-357. https://doi.org/10.9770/jssi.2017.7.2(14)

Tvaronavičienė, M., Prakapienė, D., Garškaitè-Milvydienė, K., Prakapas, R., Nawrot, Ł. 2018. Energy Efficiency in the Long-Run in the Selected European Countries. Economics and Sociology, 11(1), 245-254.https://doi.org/10.14254/2071- 789X.2018/11-1/16

World Bank study: countries need to improve the quality of pre-project preparation 2018: URL http://www.pppi.ru/news/v-mireissledovanie-vsemirnogo-banka-o-predproektnoy-podgotovke-zakonoproekt-o-gchp-v-tailande

$\mathrm{Xu}$, Y., Chang, W. 2017. Analysis and countermeasures of PPP project implementation difficulties. Open access: MATEC Web of Conferences Global Congress on Manufacturing and Management (GCMM 2016) https://doi.org/10.1051/matecconf/201710005039

\section{Acknowledgements}

The study was prepared with the support of the Russian Foundation for basic research (RFBR), grant agreement No. 19-010-00975 
Authors:

Lyudmila Anatolyevna TOLSTOLESOVA

ORCID ID: http://orcid.org/0000-0001-8991-3188

Natalya Nikolaevna YUMANOVA

ORCID ID: https://orcid.org/0000-0003-0351-4317

Ekaterina Vladimirovna MAZIKOVA

ORCID ID: https://orcid.org/0000-0002-3673-8977

Igor Nikolaevich GLUKHIKH

ORCID ID: http://orcid.org/0000-0002-0683-6138

Marina Sergeevna VOROBYOVA

ORCID ID: https://orcid.org/0000-0002-1508-4089 